ISSN: 2362-1303 (Paper) | eISSN: 2362-1311(Online)

JOURNAL OF ADVANCED ACADEMIC RESEARCH (JAAR)

December 2017

\title{
Association between the Level of Aspiration and Achievement of Students of Secondary Level
}

\section{Tek Narayan Poudel ${ }^{1}$ and Ram Krishna Maharjan ${ }^{2}$}

${ }^{1} \mathrm{PhD}$ Scholar, Mewar University, Chittorgarh, Rajasthan, India

${ }^{2}$ Research Supervisor, Retired Professor, Tribhuvan University, Kirtipur, Nepal.

\section{Corresponding Author}

Tek Narayan Poudel

Email: tekanpdl@gmail.com

\begin{abstract}
Aspiration levels play an important role in everyday decision making. In practice, however, decisions are not based on an aspiration level alone. The aspiration level and the overall probabilities of success and failure may receive special attention, but subjects will not be completely insensitive to difference within the classes of gains and losses. Aspirations have a significant impact on pupil attainment net of family background and other individual factors, but their effect is reduced when examining pupil progression. Some students, particularly from lowincome or first-generation backgrounds, in spite of having high aspirations fail to meet their goals to attend college. Aspiration is a strong desire to achieve something in life. Every people they want to be successful man in life, they want famous, popular in society, so aspiration has vague meaning and sense. In this research student of Nepal they have high aspiration in life. Some of they want social worker, doctor, pilot engineer, great motivator and great leader in future. The study was conducted among the 511 students of grade ten students of three districts of Nepal.
\end{abstract}

\section{KEYWORDS}

Achievement, Aspiration, Secondary level, Student

\section{INTRODUCTION}

Every people want to set up the route for their best aims, desires and wishes from the beginning stage. From the research it is found that every people want to become successful in near future. Some of the respondents even didn't select their fields and aims for future but their desire is to earn lots of money, do some social work, and be successful person. In next way, so that every coming generation remember them due to their social earning and effort for society. In this research, researcher found too many ambitions of respondents after getting their higher qualification. Some of the respondents want to earn lot of money, social prestige after the completion of class ten. Similarly, some want to contribute a lot for nation but for this they know about the way of achievements that is continuous work to achieve their dream. They explained 
"thousand of journey starts from single step". They have already March on step and time will come to conquer over their aspirations.

Aspirations begin to be shaped early in a child's life, but are modified by experience and the environment. Aspirations tend to decline as children mature, in response to their growing understanding of the world and what is possible, and to constraints imposed by previous choices and achievements. This decline is particularly marked for those facing multiple barriers (Akerman, 2008). The study conducted by Dwivedi showed that there was no correlation between level of aspiration and achievement. He discussed about the reason may be that most of the students were found to be over aspirant, i.e., they expect more and do less. In such a situation one may expect a negative correlation. The reason for non-significant results may be that the students are over aspirant but not so over aspirant to warrant a negative correlation (2012).

Aspirations regarding completion of secondary school that predict achievement outcomes are related to factors amenable to intervention. Relationships were found among academic achievement and self-reported educational aspirations, motivation, affiliation with peers and teachers, and attributions. Students who indicated no aspiration to complete a school qualification were indistinguishable from those with low or moderate aspirations, and the analyses supported only two divergent groups comprising students with either low or high aspiration to complete qualifications. Aspirations were significantly related to different patterns of motivation, affiliation, and attributions predictive of academic achievement. Students of different ethnicity and gender also fell unequally across the two groups. These results suggested that promoting low or even moderate expectations and aspirations for student achievement reinforced lower academic achievement (Walkey, 2013).

From the rigorous review of the previous study, the study got the knowledge of concept of dietary habit, study habit and level of aspiration. The findings of various studies supported to develop the research problem and objective and hypothesis of this study. The study identified the various theories related to this study and adopted the 'Social Learning Theory' to conduct this study. The previous study showed that there was significant relationship between the dietary habit and academic achievement, study habit and academic achievement and level of aspiration and academic achievements. The study found the research gap in the context of Nepalese students. So, the study set the major research question to explore the practices of dietary habit, study habit and level of aspiration and its effect on the academic achievement of SLC students of government and private schools of Nepal.

\section{METHODS}

The study was conducted in Kaski, Syangja and Parbat district based on the descriptive research design which described the practices and association between study habits and achievements of class ten students of Nepal. The study had collected the quantitative data by using the structured survey questionnaires. The random sampling technique was used to select the students from selected districts of Nepal. All total 511 respondents were selected from the both public and private 
ISSN: 2362-1303 (Paper) | eISSN: 2362-1311(Online)

JOURNAL OF ADVANCED ACADEMIC RESEARCH (JAAR)

December 2017

schools. The method of statistical analysis of data was completed by using the SPSS 16 version. The regression analysis was done to find out the effect of study habit on academic achievements.

\section{RESULTS AND DISCUSSION}

This study examines that how different combinations of aspirations, expectations and school achievement can influence students' future educational behavior. The study shows that students with high aspirations or high expectations have higher school achievement than those with both low aspirations and low expectations. Furthermore, complete alignment between high aspirations, high expectations and high achievement is the most important predictor of future educational behavior among students.

\section{Future plan of students after completion of SLC}

The students were asked about their future plan to know their aspiration. Positive aspiration is good for students for the better improvement in future because it encourages doing the hard labour.

Table 1: Future plan of students after completion of SLC Future plan of students after completion of SLC

\begin{tabular}{|c|c|c|c|c|c|}
\hline & \multicolumn{2}{|c|}{ Sex of respondents } & \multirow{2}{*}{ Total } \\
\hline & & & Male & Female & \\
\hline \multirow{6}{*}{ I will search a job } & \multirow{3}{*}{ Yes } & Count & 158 & 163 & 321 \\
\hline & & $\%$ within total & 49.2 & 50.8 & 100.0 \\
\hline & & $\%$ within Sex of respondents & 63.5 & 62.2 & 62.8 \\
\hline & \multirow{3}{*}{ No } & Count & 91 & 99 & 190 \\
\hline & & $\%$ within total & 47.9 & 52.1 & 100.0 \\
\hline & & \% within Sex of respondents & 36.5 & 37.8 & 37.2 \\
\hline \multirow{6}{*}{$\begin{array}{l}\text { Find an apprenticeship } \\
\text { for further study after } \\
\text { SLC }\end{array}$} & \multirow{3}{*}{ Yes } & Count & 187 & 198 & 385 \\
\hline & & $\%$ within total & 48.6 & 51.4 & 100.0 \\
\hline & & \% within Sex of respondents & 75.1 & 75.6 & 75.3 \\
\hline & \multirow{3}{*}{ No } & Count & 62 & 64 & 126 \\
\hline & & $\%$ within total & 49.2 & 50.8 & 100.0 \\
\hline & & \% within Sex of respondents & 24.9 & 24.4 & 24.7 \\
\hline \multirow{6}{*}{$\begin{array}{l}\text { Take a rest one year } \\
\text { before continuing in } \\
\text { education or } \\
\text { employment after SLC }\end{array}$} & \multirow{3}{*}{ Yes } & Count & 12 & 17 & 29 \\
\hline & & $\%$ within total & 41.4 & 58.6 & 100.0 \\
\hline & & \% within Sex of respondents & 4.8 & 6.5 & 5.7 \\
\hline & \multirow{3}{*}{ No } & Count & 237 & 245 & 482 \\
\hline & & $\%$ within total & 49.2 & 50.8 & 100.0 \\
\hline & & \% within Sex of respondents & 95.2 & 93.5 & 94.3 \\
\hline \multirow{2}{*}{$\begin{array}{l}\text { I will start my own } \\
\text { business in future }\end{array}$} & \multirow{2}{*}{ Yes } & Count & 198 & 204 & 402 \\
\hline & & $\%$ within total & 49.3 & 50.7 & 100.0 \\
\hline
\end{tabular}




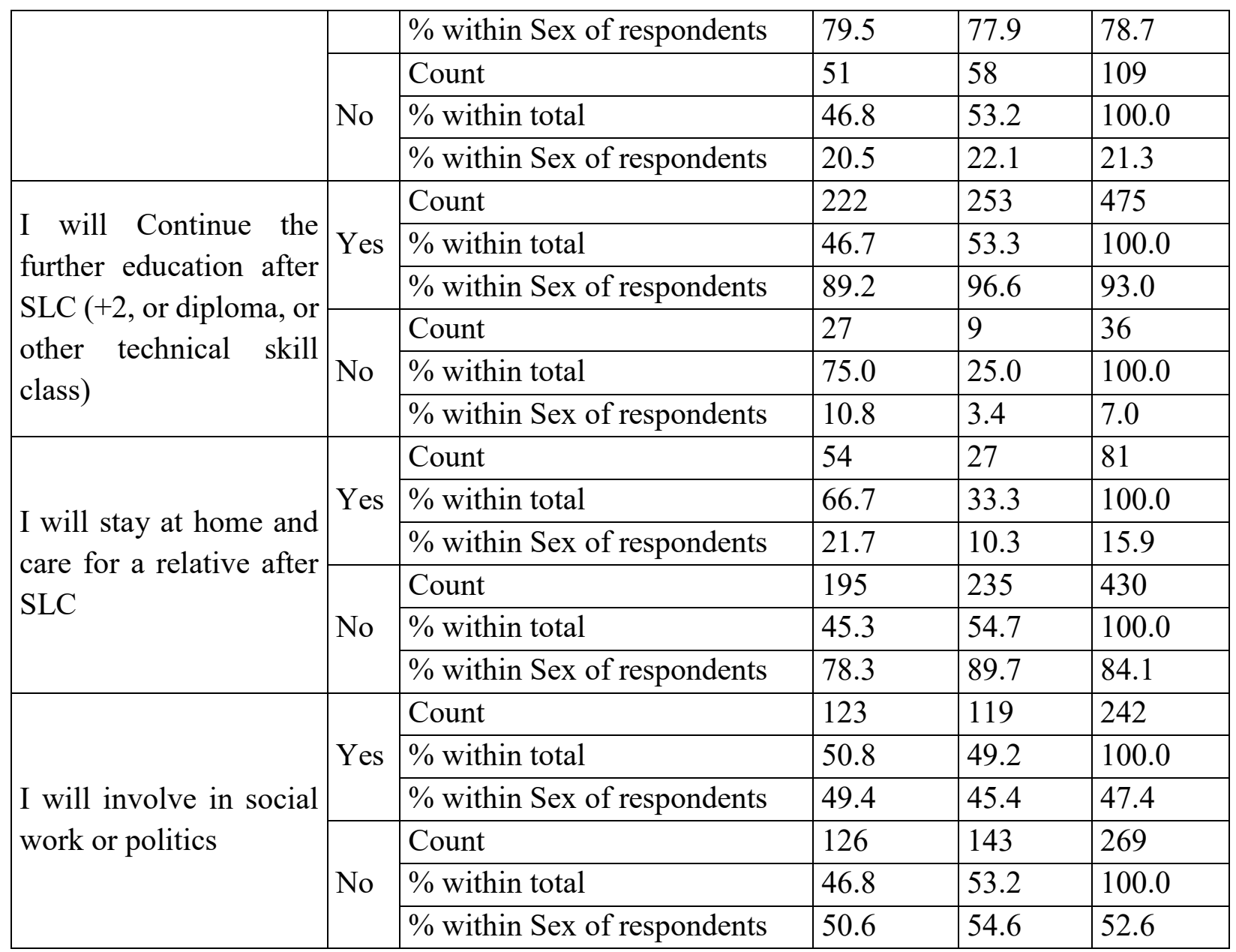

Source: field survey 2014.

The data presented in the Table 1 showed that $62.8 \%$ students said that they would search job after completion of SLC, $75.3 \%$ said that they would find an apprenticeship for further study, only 5.7\% said that they would like to take rest for one year before the continuation in education or employment after SLC, $78.7 \%$ would start their own business in future, $93 \%$ would continue the further education, $47.4 \%$ would involve in social work or politics. Overall it can be said that the future plan of most of the students was found positive after the completion of SLC. Very few students reported that they want to take rest after completing SLC.

\section{Feeling about the future after 10 years}

Students were also asked about their feelings of future after 10 years from the date of SLC. It is said that present day is the golden day for people, but people always worry for the future. Future is unknown and uncertain so people try their best to make their future good. Youth generation is the sources of development and changes of the nation for future so that their commitment should be positive. 
ISSN: 2362-1303 (Paper) | eISSN: 2362-1311(Online)

JOURNAL OF ADVANCED ACADEMIC RESEARCH (JAAR)

December 2017

The data showed that there were $48.7 \%$ male and $51.3 \%$ female students participated in the study. Among them, $22.5 \%$ male followed by $27.8 \%$ female students were found very optimistic that they would get the career of their choice after 10 years. Similarly, $16.2 \%$ male and $18.4 \%$ females were quite optimistic. It was good that in total $50.3 \%$ students were very optimistic followed by $34.6 \%$ were quite optimistic. Data showed that around $14 \%$ students were pessimistic when thinking about the career of their own choice after 10 years from SLC completion. It made compelling to think about the future of those $14 \%$ students that the pessimistic feeling could affect negatively in their achievement.

Table 2: Feeling about the future after 10 years

Sex wise Feeling about the future after 10 years

\begin{tabular}{|c|c|c|c|c|c|c|c|c|}
\hline & & & $\begin{array}{l}\text { Very } \\
\text { Optimistic }\end{array}$ & $\begin{array}{l}\text { Quite } \\
\text { Optimisti } \\
\text { c }\end{array}$ & $\begin{array}{l}\text { Quite } \\
\text { Pessimistic }\end{array}$ & $\begin{array}{l}\text { Very } \\
\text { Pessimisti } \\
\text { c }\end{array}$ & \begin{tabular}{|l|} 
Not \\
sure/Don't \\
know
\end{tabular} & Total \\
\hline I will get & Malo & $\mathrm{N}$ & 115 & 83 & 37 & 9 & 5 & 249 \\
\hline the career & viale & $\%$ & 22.5 & 16.2 & 7.2 & 1.8 & 1.0 & 48.7 \\
\hline of my & & $\mathrm{N}$ & 142 & 94 & 16 & 10 & 0 & 262 \\
\hline choice & remale & $\%$ & 27.8 & 18.4 & 3.1 & 2.0 & 0.0 & 51.3 \\
\hline & & $\mathrm{N}$ & 257 & 177 & 53 & 19 & 5 & 511 \\
\hline Total & & $\%$ & 50.3 & 34.6 & 10.4 & 3.7 & 1.0 & 100.0 \\
\hline I will have & & $\mathrm{N}$ & 62 & 89 & 63 & 18 & 17 & 249 \\
\hline enough & Male & $\%$ & 12.1 & 17.4 & 12.3 & 3.5 & 3.3 & 48.7 \\
\hline money to & Fema & $\mathrm{N}$ & 43 & 124 & 56 & 19 & 20 & 262 \\
\hline $\begin{array}{l}\text { live } \\
\text { comfortably }\end{array}$ & le & $\%$ & 8.4 & 24.3 & 11.0 & 3.7 & 3.9 & 51.3 \\
\hline & & $\mathrm{N}$ & 105 & 213 & 119 & 37 & 37 & 511 \\
\hline Total & & $\%$ & 20.5 & 41.7 & 23.3 & 7.2 & 7.2 & 100.0 \\
\hline I will be able & \begin{tabular}{l|l} 
le & Mal
\end{tabular} & $\mathrm{N}$ & 159 & 47 & 24 & 13 & 6 & 249 \\
\hline to cope with & $\mathrm{h}$ e & $\%$ & 31.1 & 9.2 & 4.7 & 2.5 & 1.2 & 48.7 \\
\hline any barriers to & $\mathrm{Fe}$ & $\mathrm{N}$ & 138 & 78 & 32 & 12 & 2 & 262 \\
\hline $\begin{array}{l}\text { success that I } \\
\text { meet in future }\end{array}$ & \begin{tabular}{l|l}
$\mathrm{I}$ & $\mathrm{mal}$ \\
$\mathrm{e}$ & $\mathrm{e}$
\end{tabular} & $\%$ & 27.0 & 15.3 & 6.3 & 2.3 & 0.4 & 51.3 \\
\hline Total & & $\mathrm{N}$ & 297 & 125 & 56 & 25 & 8 & 511 \\
\hline lotal & & $\%$ & 58.1 & 24.5 & 11.0 & 4.9 & 1.6 & 100.0 \\
\hline In overall, & Male & $\mathrm{N}$ & 105 & 70 & 44 & 19 & 11 & 249 \\
\hline thinking & IVIale & $\%$ & 20.5 & 13.7 & 8.6 & 3.7 & 2.2 & 48.7 \\
\hline about likely & & $\mathrm{N}$ & 119 & 78 & 45 & 14 & 6 & 262 \\
\hline
\end{tabular}


ISSN: 2362-1303 (Paper) | eISSN: 2362-1311(Online)

JOURNAL OF ADVANCED ACADEMIC RESEARCH (JAAR)

December 2017

\begin{tabular}{|l|l|l|l|l|l|l|l|l|}
\hline $\begin{array}{l}\text { life in ten } \\
\text { years' time }\end{array}$ & $\begin{array}{l}\text { Fema } \\
\text { le }\end{array}$ & $\%$ & 23.3 & 15.3 & 8.8 & 2.7 & 1.2 & 51.3 \\
\hline \multirow{2}{*}{ Total } & $\mathrm{N}$ & 224 & 148 & 89 & 33 & 17 & 511 \\
\cline { 2 - 8 } & $\%$ & 43.8 & 29.0 & 17.4 & 6.5 & 3.3 & 100.0 \\
\hline
\end{tabular}

Source: field survey 2014.

Similarly, the students were asked about their feeling of earning money in future. Out of all respondents, $20.5 \%$ students were found very optimistic followed by $41.7 \%$ were quite optimistic that they would had enough money to live comfortably in future. In relation to the genders' perspective; $12.1 \%$ male were very optimistic followed by $17.4 \%$ were quite optimistic whereas $8.4 \%$ female students followed by $24.3 \%$ were quite optimistic regarding the earning money in the next 10 years (Table 2).

Students were also reported their level of hope in relation to their capacity to cope any barriers of future. In total, $58.1 \%$ students were very optimistic followed by $24.5 \%$ were quite optimistic that they would be able to cope with any barriers to success that they met in future. Gender wise, $31.1 \%$ male were very optimistic and $9.2 \%$ were quite optimistic whereas $27 \%$ females were very optimistic followed by $15.3 \%$ were quite optimistic. There was similarity between the male and female students in their feeling about their ability to cope the problem in future.

In total, only 3.3\% students reported that they were unknown about their future life. They were not sure that whether they would get their future life as expected or not. They were in confused situation.

\section{Future profession Frequencies}

Every people have their own choice and interest areas in future. The students were asked about their future plan of profession.

Table 3: Future profession Frequencies

\begin{tabular}{|c|c|c|c|}
\hline \multicolumn{4}{|c|}{ Future profession Frequencies } \\
\hline & & \multicolumn{2}{|c|}{ Responses } \\
\hline & & $\mathrm{N}$ & Percent $(\%)$ \\
\hline \multirow{2}{*}{ 总 } & Agriculture & 38 & 7.8 \\
\hline & Government job & 254 & 52.0 \\
\hline \multirow{6}{*}{ 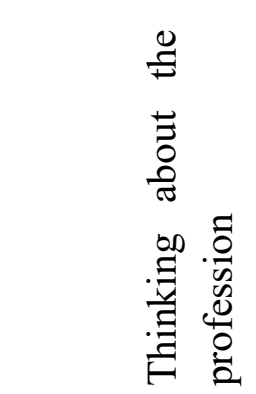 } & Own private organization & 71 & 14.5 \\
\hline & Non -governmental organization & 13 & 2.7 \\
\hline & $\begin{array}{l}\text { Service in private organization owned by } \\
\text { other }\end{array}$ & 20 & 4.1 \\
\hline & Abroad jobs & 50 & 10.2 \\
\hline & Business & 126 & 25.8 \\
\hline & Politics & 30 & 6.1 \\
\hline
\end{tabular}


ISSN: 2362-1303 (Paper) | eISSN: 2362-1311(Online)

JOURNAL OF ADVANCED ACADEMIC RESEARCH (JAAR)

December 2017

a. Dichotomy group tabulated at value 1 .

Source: field survey 2014.

The data tabulated in the Table 3 showed that $7.8 \%$ had plan to involve in agriculture sectors, $52 \%$ had plan to do the government job, $14.5 \%$ had reported that they wanted to do the work in their own private organization, $2.7 \%$ wanted to work in non-governmental organization, $4.1 \%$ wanted to work in private organization owned by other, $10.2 \%$ wanted to go abroad for job, $25.8 \%$ wanted to do the business and $6.1 \%$ wanted to the politics in future. Among all respondents, it was observed that more than $50 \%$ students wanted to join government job, which also showed that first priority of people is to do the government job in Nepal.

\section{Future Achievement Frequencies}

The students were also asked about their interest of future achievement. The students had multiple choices so that they were allowed to choose more than one option of future achievement.

Table 4: Future Achievement Frequencies

\begin{tabular}{|c|c|c|c|}
\hline \multicolumn{4}{|c|}{ Future Achievement Frequencies } \\
\hline & & \multicolumn{2}{|c|}{ Responses } \\
\hline & & $\mathrm{N}$ & Percent $(\%)$ \\
\hline \multirow{13}{*}{ 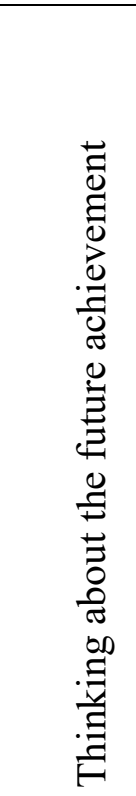 } & Owning my own home & 306 & 59.9 \\
\hline & Going on holiday abroad at least twice a year & 64 & 12.5 \\
\hline & Owning a car & 96 & 18.8 \\
\hline & $\begin{array}{l}\text { Being in a stable long term relationship with high class } \\
\text { people }\end{array}$ & 122 & 23.9 \\
\hline & Having a family with children & 222 & 43.4 \\
\hline & Eating out at nice restaurants at least twice a month & 15 & 2.9 \\
\hline & Living in a different part of the country & 35 & 6.8 \\
\hline & Moving out of your parents' home & 37 & 7.2 \\
\hline & Being free of responsibility & 67 & 13.1 \\
\hline & Having a university degree & 233 & 45.6 \\
\hline & Having a job I love & 234 & 45.8 \\
\hline & Being rich enough to not have to work & 39 & 7.6 \\
\hline & Being famous in media & 103 & 20.2 \\
\hline
\end{tabular}

Source: field survey 2014.

The data tabulated in the Table 4 showed that in total $59.9 \%$ wanted to achieve their own house in future, $12.5 \%$ said that they wanted to celebrate holiday in abroad at least twice a year, $18.8 \%$ expected to get own car. In total $23.9 \%$ said that they wanted to keep stable long term relationship with high class people, $43.4 \%$ wanted to have their family with their children, $2.9 \%$ also wanted to enjoy eating out at nice restaurants at least twice a month, $6.8 \%$ reported that they 
ISSN: 2362-1303 (Paper) | eISSN: 2362-1311(Online)

JOURNAL OF ADVANCED ACADEMIC RESEARCH (JAAR)

December 2017

wanted to get the experience of living in a different part of the country, $7.2 \%$ were interested to move out of parents' home, $13.1 \%$ wanted to be free from responsibility.

The data of Table 4 also showed that $45.6 \%$ wanted to achieve high degree from university, $45.8 \%$ said that they wanted to do their jobs as they liked, $7.6 \%$ wanted to become rich enough so that they need not to work hard, $20.2 \%$ said that they wanted to be famous in media.

The above data showed that every student had their specific interests. Most of the students have practice to go aboard for the job and study and finally they forgot their responsibilities of Nation. It is good to know that no students reported that they wanted to live in another country than their motherland.

\section{Future happiness Frequencies}

The study had tried to collect the data of sources of happiness for the students. Every people have their own future plan. The main objective of their plan is to get the happiness in future. So the students were asked about the sources of their happiness.

Table 5: Future happiness Frequencies

\begin{tabular}{|l|l|l|l|}
\hline \multicolumn{3}{|l|}{ Future happiness Frequencies } \\
\hline \multicolumn{5}{|l|}{} & Responses \\
\cline { 3 - 4 } \multicolumn{1}{|l}{$\begin{array}{l}\text { what makes happy } \\
\text { in future }\end{array}$} & $\begin{array}{l}\text { Being in a stable relationship with high class } \\
\text { people }\end{array}$ & 79 & 15.5 \\
\cline { 2 - 4 } & Living in a place you like having children & 276 & 54.0 \\
\cline { 2 - 4 } & Having active hobbies like sports, music, etc & 98 & 19.2 \\
\cline { 2 - 4 } & Having enough money to buy what you want, & 108 & 21.1 \\
\cline { 2 - 4 } & Being successful in your chosen career & 363 & 71.0 \\
\cline { 2 - 4 } & Having a spiritual/ religious element in your life & 63 & 12.3 \\
\cline { 2 - 4 } & Being healthy & 357 & 69.9 \\
\cline { 2 - 4 } & Being famous & 159 & 31.1 \\
\hline
\end{tabular}

Source: field survey 2014.

The data presented in the Table 5 showed that in total $15.5 \%$ said that being in a stable relationship with high class people would be the source of happiness, $54 \%$ said that living in a place of their own choice with children, $19.2 \%$ said that involving in sports, music, $21.1 \%$ said that having enough money to buy what they wanted, $71 \%$ said that being successful in their chosen careers, $12.3 \%$ said that being healthy and $31.1 \%$ said that being famous would be the sources of happiness. 
ISSN: 2362-1303 (Paper) | eISSN: 2362-1311(Online)

JOURNAL OF ADVANCED ACADEMIC RESEARCH (JAAR)

December 2017

\section{Correlation between the future plan of students and their academic achievements}

Current position and effort of people depend on their future plan also. If people are optimistic in future work, then it gives the positive energy and people is encouraged to do hard labor. Similarly, if a person is pessimistic in future then people will be frustrated and discouraged to do hard work. It is assumed that there is effect of future plan on the academic achievement of students. The study analyzed the relationship between the future plan of students and their academic achievement.

Table 6: Correlation between the future plan of students and their academic achievements

\begin{tabular}{|c|c|c|c|c|c|c|c|c|c|}
\hline \multicolumn{9}{|c|}{ Correlations } & \multirow[b]{2}{*}{ 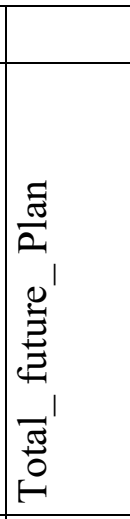 } \\
\hline & & 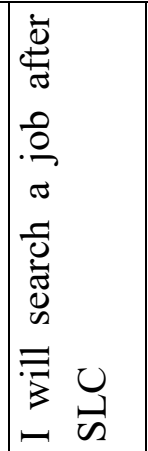 & 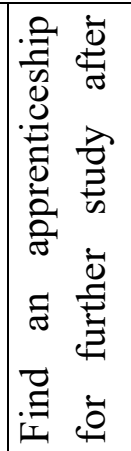 & 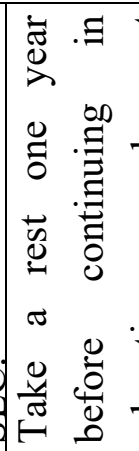 & 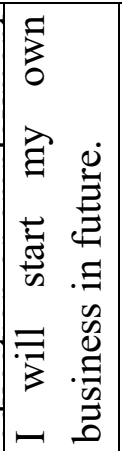 & 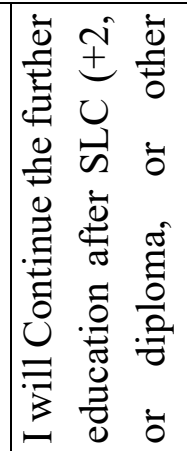 & 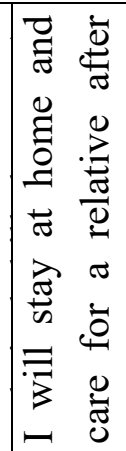 & 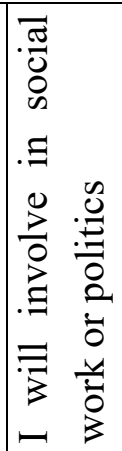 & \\
\hline \multirow{3}{*}{$\begin{array}{l}\text { Current } \\
\text { position in } \\
\text { class }\end{array}$} & \begin{tabular}{|l|} 
Pearson \\
Correlation
\end{tabular} & $-.118^{* *}$ & $.094^{*}$ & .018 & -.045 & .049 & -.021 & .038 & -.006 \\
\hline & Sig. (2-tailed) & .008 & .033 & .689 & .307 & .272 & .631 & .388 & .896 \\
\hline & $\mathrm{N}$ & 511 & 511 & 511 & 511 & 511 & 511 & 511 & 511 \\
\hline \multirow{3}{*}{$\begin{array}{l}\text { Expected } \\
\text { position in } \\
\text { SLC result }\end{array}$} & $\begin{array}{l}\text { Pearson } \\
\text { Correlation }\end{array}$ & $-.297^{* *}$ & $.111^{*}$ & $-168^{* *}$ & -.077 & -.024 & -.050 & $-130^{* *}$ & $-213 * *$ \\
\hline & Sig. (2-tailed) & .000 & .012 & .000 & .083 & .591 & .261 & .003 & .000 \\
\hline & $\mathrm{N}$ & 511 & 511 & 511 & 511 & 511 & 511 & 511 & 511 \\
\hline \multicolumn{9}{|c|}{ *. Correlation is significant at the 0.01 level (2-tailed) } & \\
\hline \multicolumn{9}{|c|}{ Correlation is significant at the 0.05 level (2-tailed). } & \\
\hline
\end{tabular}

Source: field survey 2014.

The data presented in the Table 6 showed that there is correlation between the current position of students in class and two indicators of future plan (I will search a job after SLC \& Find an apprenticeship for further study after SLC) at the 0.01 and 0.05 level of significant. But there was no correlation between the rest 5 indicators of future plan and current position of students in class.

The study also explored the analysis of correlation between the future plan and expected position in SLC result. The findings showed that there was significant correlation between four indicators of future plan (I will search a job after SLC, find an apprenticeship for further study after SLC, take a rest one year before continuing in education or employment after SLC, I will involve in social work or politics) and expected position in SLC result at 0.01 and 0.05 level of 
significant. There was no correlation between the rest 3 indicators of future plan and expected position in SLC result.

It was observed that the students who expected the job after completion of SLC had negative correlation with the current position in classroom and expected position in SLC result. Similarly, who wanted to take rest for one year after completion of SLC before continuing further study or employment and who wanted to involve in social work or politics had also negative correlation with expected position in SLC result. It was interesting that the findings showed some similarity with the real practices in Nepal that there is no need of academic qualification to join in social work or politics which discouraged to do the hard labour to get the good position in education sectors.

Similarly, who wants to involve in economic activities immediately after SLC or wants to take rest after SLC can negatively effect in the academic performances. Statistically, it was found that there was no significant correlation between the total future plan and current position of students in class because the $\mathrm{P}$ value was greater than the 0.05 significant levels. Whereas, there was significant correlation between the total future plan and expected position of students in SLC result at $\mathrm{P}=.000$.

\section{Correlation between the feeling about 10 year's future life and academic achievements.}

Feeling about the future life supports to take the decision in present situation. With the rapid development of science and technology has changed the society into global village. People are more conscious about their future life so they travel from one country to another country in the search of bright future. It is observed that in the global market; migration of youth is high. In Nepal also, abroad migration becomes one culture among the youth. They feel that their future would be better in abroad market than their birth place. In such situation, the study asked the SLC students about their feeling of 10 year's future life.

From the statistical analysis of correlations, there was no significant correlation between the feeling about the 10-year's future life and current position in class and expected position in SLC result because the $P$ value was greater than 0.05 . In this study area, there was no any effect of level of aspiration of students in their academic achievement or performances.

Table 7: Correlation between the feeling about 10 year's future life and academic achievements.

\begin{tabular}{|c|c|c|c|c|c|c|c|c|c|c|}
\hline \multicolumn{11}{|l|}{ Crosstab } \\
\hline \multirow[b]{2}{*}{$\begin{array}{l}\text { Feeling } \\
\text { about } 10 \\
\text { years life }\end{array}$} & \multicolumn{3}{|c|}{ Current position in class } & \multirow[b]{2}{*}{ Total } & \multicolumn{5}{|c|}{ Expected position in SLC result } & \multirow[b]{2}{*}{ Total } \\
\hline & $\begin{array}{l}\text { 1-3 } \\
\text { position }\end{array}$ & $\begin{array}{l}\text { 4-10 } \\
\text { position }\end{array}$ & $\begin{array}{l}\text { Above } \\
10 \\
\text { position }\end{array}$ & & $\begin{array}{l}\text { Distinctio } \\
\mathrm{n}\end{array}$ & $\begin{array}{l}1^{\text {st }} \\
\text { division }\end{array}$ & \begin{tabular}{|l|}
$2^{\text {nd }}$ \\
divisio \\
$n$
\end{tabular} & Pass & Fail & \\
\hline
\end{tabular}


ISSN: 2362-1303 (Paper) | eISSN: 2362-1311(Online)

JOURNAL OF ADVANCED ACADEMIC RESEARCH (JAAR)

December 2017

\begin{tabular}{|l|l|l|l|l|l|l|l|l|l|l|}
\hline $\begin{array}{l}\text { Very } \\
\text { Optimistic }\end{array}$ & 30 & 90 & 104 & 224 & 60 & 120 & 37 & 7 & 0 & 224 \\
\hline $\begin{array}{l}\text { Quite } \\
\text { Optimistic }\end{array}$ & 12 & 80 & 56 & 148 & 26 & 86 & 31 & 4 & 1 & 148 \\
\hline $\begin{array}{l}\text { Quite } \\
\text { Pessimistic }\end{array}$ & 10 & 34 & 45 & 89 & 18 & 48 & 21 & 2 & 0 & 89 \\
\hline $\begin{array}{l}\text { Very } \\
\text { Pessimistic }\end{array}$ & 6 & 13 & 14 & 33 & 9 & 15 & 7 & 2 & 0 & 33 \\
\hline Not sure & 3 & 6 & 8 & 17 & 3 & 9 & 4 & 1 & 0 & 17 \\
\hline Total & 61 & 223 & 227 & 511 & 116 & 278 & 100 & 16 & 1 & 511 \\
\hline Correlation & & & & & & & & & \\
\hline
\end{tabular}

\section{Correlations}

\begin{tabular}{|l|l|l|l|}
\hline \multicolumn{2}{|c|}{} & Current position in class & $\begin{array}{l}\text { Expected position in SLC } \\
\text { result }\end{array}$ \\
\hline $\begin{array}{l}\text { Feeling about } \\
\text { the } 10 \text { years } \\
\text { future life }\end{array}$ & Pearson Correlation & -.006 & .071 \\
\cline { 2 - 4 } & Sig. (2-tailed) & .897 & .106 \\
\hline **. Correlation is significant at the 0.01 level (2-tailed). & 511 \\
\hline
\end{tabular}

\section{Source: field survey 2014}

The data presented in the Table no. 7 showed that there was no significant different between those students who were very optimistic or pessimistic in determining their current position in class and expected position in SLC result because the students whose position was in top 3 were also very pessimistic whereas the students whose position was above 10 were also very optimistic about their coming future life. Similarly, there was no significant effect of feeling of future life on expected position in SLC result also.

\section{CONCLUSIONS}

The study found that the practices of study habit are directly related to the academic achievements. Social background of the students, their family support and the desire of student labor also determine their academic success. Poor performance will show the poor result. The study found the significant effect of study habit on current position of student in class, expected position in SLC result, quiz contest, speech competition, out of school activities and interaction with teacher. The effect of study habit was not more than $8 \%$ in any types of achievements. Study habit was not related with the folk song competition because there is no subject related to the music; singing a song. The result shows the need of significant improvement in study habit. The teacher and guardians should be aware on the study habit along with the students. So, public and private both schools' management should plan some orientation and training program for teacher to train on the skill of study habit. 
ISSN: 2362-1303 (Paper) | eISSN: 2362-1311(Online)

JOURNAL OF ADVANCED ACADEMIC RESEARCH (JAAR)

December 2017

\section{REFERENCES}

Akerman, L. M. (2008). Determinants of Aspirations. UK: University of London.

Dunne, F. E. (1979). Sex differences in the educational and occupational. Journal of Vocational Behaviour, 18 (1), 56-66.

Dwivedi, V. (2012). Relationship between level of aspiration and achievement in social sciences . IJREISS .

Dwivedi, V. (2012). RELATIONSHIP BETWEEN LEVEL OF ASPIRATION AND ACHIEVEMENT IN SOCIAL SCIENCES. International Journal of Research in Engineering, IT and Social Sciences (IJREISS), 2 (2), 61-66.

Glass, O. (1974). Birth order, verbal intelligence and educational aspirations. Child Development , 807-811.

Goswami, M. A. (2013). Level of aspiration of undergraduate students in relation to their sex and socio-economic status. International Journal of Humanities and Social Sciences , 79-86.

Hecht, D. (2013). The Neural Basis of Optimism and Pessimism. Experimental Neurobiol , 22 (3), 173-199.

Kate Hellenga, M. S. (2002). FRICAN AMERICAN ADOLESCENT MOTHERS' VOCATIONAL ASPIRATION-EXPECTATION GAP: INDIVIDUAL, SOCIAL AND ENVIRONMENTAL INFLUENCES. Psychology of Women Quarterly , 26, 200-212.

Khattab, N. (2015, JAN 21 ). Students' aspirations, expectations and school achievement: what really matters? British Educational Research Journal .

Kulkarni, S. (2010). Academic Aspiration and Postsecondary Attainment: Evidence from the National Education Longitudinal Study of 1988 (NELS:88).

Lakshmanan, A. (2004). A LONGITUDINAL STUDY OF ADOLESCENT EDUCATIONAL ASPIRATIONS AND THEIR RELATIONSHIP TO COLLEGE CHOICE USING HIERARCHICAL LINEAR MODELING AND GROUP-BASED MIXTURE MODELING. USA: Louisiana State University.

McCracken, J. \&. (1991). Differences between rural and urban schools, students characteristics, and student aspirations in Ohio. Journal of Research in Rural Education , 7 (2), 29-40.

Park, H. (2008). Effect of single parenthood on educational aspiration and students disengagement in Korea. Demographic Research , 18 (13), 377-408.

Portsmouth, U. o. (2013). Aspirations, Expectations and Achievement: A project for Portsmouth City Council. UK.

Rothon, C. (2011). Structural and socio-psychological influences on adolescents educational aspirations and subsequent academic achievement. Social Psychology of Education , 14 (2), 209-231.

Singh, Y. (2011). A study of educational aspiration in secondary school students. International Referred Research Journal , 3 (25). 
ISSN: 2362-1303 (Paper) | eISSN: 2362-1311(Online)

JOURNAL OF ADVANCED ACADEMIC RESEARCH (JAAR)

December 2017

Walkey, J. M. (2013). Low expectations equal no expectations: Aspirations, motivation and achievement in secondary school. Contemporary Educational Psychology, 306-315. 